This item was submitted to Loughborough's Research Repository by the author.

Items in Figshare are protected by copyright, with all rights reserved, unless otherwise indicated.

\title{
Content analysis in social and environmental reporting research: trends and challenges
}

PLEASE CITE THE PUBLISHED VERSION

http://dx.doi.org/10.1108/JAAR-04-2013-0027

\section{PUBLISHER}

(C) Emerald Group Publishing Limited

\section{VERSION}

AM (Accepted Manuscript)

\section{PUBLISHER STATEMENT}

This work is made available according to the conditions of the Creative Commons Attribution-NonCommercialNoDerivatives 4.0 International (CC BY-NC-ND 4.0) licence. Full details of this licence are available at: https://creativecommons.org/licenses/by-nc-nd/4.0/

\section{LICENCE}

CC BY-NC-ND 4.0

\section{REPOSITORY RECORD}

Vourvachis, Petros, and Therese Woodward. 2019. "Content Analysis in Social and Environmental Reporting Research: Trends and Challenges”. figshare. https://hdl.handle.net/2134/19623. 


\title{
Content analysis in social and environmental reporting research: trends and challenges
}

\author{
P. Vourvachis and T. Woodward
}

\begin{abstract}
Purpose - The present study comprehensively reviews the use of content analysis in social and environmental reporting research. It explores how the relevant literature has evolved over time and particularly how recent developments have affected the validity and reliability challenges that researchers face when executing the method.

Design/methodology/approach - The paper combines a quasi-systematic review of the literature employing content analysis (examining a sample of 251 studies published over the last 40 years in a wide array of journals with interest in the field), with a largely interpretive meta-analysis, using an index, considering the research questions asked and frameworks used as well as the specific content analysis decisions.

Findings - A number of issues of concern in the use of the method are identified, mainly over comparability and reliability of coding schemes. Potential explanations are developed and methodological refinements that could enhance the usefulness of content analysis methods in social and environmental reporting research are subsequently proposed.

Originality/value - The paper contributes to the literature by offering a critical and comprehensive review of the method's theoretical underpinnings and application in social and environmental reporting research, and by describing changing patterns in content analysis, in order to help build a more secure foundation for future work.
\end{abstract}

Keywords: Social and environmental reporting, content analysis, validity, reliability

Article Classification: Literature review

\section{Introduction}

Content analysis has become a widely used method of analysis in a variety of settings, including anthropology, linguistics, social psychology, sociology of knowledge, communication, and increasingly organisation studies (Duriau et al., 2007; Krippendorff, 2013). Within the Social and Environmental Reporting (SER) ${ }^{1}$ research, it appears to be "the research method that is most commonly used to assess organisations' social and environmental disclosures" (Milne and Adler, 1999, p. 237). It can be associated with investigations where the content of communication serves as the basis for inference (Weber, 1990) but is most often viewed in SER as being strictly quantitative, involving "gathering data... [and] codifying qualitative information... into categories in order to

\footnotetext{
${ }^{1}$ For the purposes of this paper, the term Social and Environmental Reporting has an equivalent meaning to the term Corporate Social Reporting, which Gray et al. (1987) defined as "the process of communicating the social and environmental effects of organisations' economic actions to particular interest groups within society and to society at large" (p. ix). The chosen term is consistent with a number of recent studies, such as Guthrie et al. (2008) and Mahadeo et al. (2011).
} 
derive quantitative scales of varying levels of complexity" (Abbot and Monsen, 1979, p. 504).

Considering the wide employment of the method and its idiosyncratic approach to analysis (by transforming, by and large, 'qualitative' to 'quantitative' data), several papers have identified and discussed methodological issues regarding its use in SER research. Most papers however seem to focus on the measurement (e.g. Hackston and Milne, 1996; Unerman, 2000) and/or sampling decisions (e.g. Unerman, 2000; Guthrie et al., 2008), whilst others suggest more complex coding schemes (Beck et al., 2010) or practical ways to address subjective choices (Steenkamp and Northcott, 2007). Aspects such as the research questions asked, theoretical frameworks used as well as categories and overall research designs employed to investigate those questions seem to have been largely overlooked, despite the considerable implications that these decisions may have on the validity and reliability of the studies' findings.

To address this lacuna, this paper comprehensively reviews the theory and practice of content analysis in SER research, with particular reference to validity and reliability considerations. Empirical grounding for some of the arguments in this paper is provided by a critical review of the use of the method in a comprehensive sample of SER studies published over the last 40 years. This allows for the paper to additionally explore how the relevant literature has evolved over time, and also how recent developments have affected the validity and reliability challenges that researchers face when executing the method. In doing so, it aims to inform and facilitate future related research ${ }^{2}$.

The paper proceeds as follows. The next sections provide background information on content analysis, along with a description of the research approach. Then, the particular challenges in the use of the method in the context of SER research are discussed, with reference to the reviewed studies and to the identified trends in the literature. The concluding section discusses the study's findings and proposes methodological refinements that could potentially enhance the utility of content analysis in SER research.

\section{Varieties of content analysis}

Content analysis has a long history in social research, with evidence of the use of the method in studies of censorship going back to seventeenth century (Stone et al., 1966). Its intellectual roots, however, can be traced even further back in human history, to the beginning of the conscious use of symbols, voice and especially writing (Krippendorff, 2013). One of the longest and most prominent debates within the content analysis domain, originated in the late 1940s and 1950s (see e.g. Lasswell, 1949; Osgood, 1959; and more recently Boyatzis, 1998; Krippendorff, 2013) considers whether it is a strictly

\footnotetext{
${ }^{2}$ It also seems particularly topical to undertake such an investigation, given that "[t]he literature has flourished from a trickle or articles in the 1970s and 1980s into a rich and diverse field" (Thomson, 2007, p. 29). Indeed, the recent widespread organisational adoption of the Global Reporting Initiative and standalone reporting (Milne and Gray, 2007; Gray and Laughlin, 2012), which is concurrent with the wide availability of archived data on the internet (Rowbottom and Lymer, 2009), with a long-established, great potential for SER research (Cowton, 1998), perhaps can all explain Thomson's finding that content analysis consisted the predominant method in his 700 articles review sample throughout his (similar to the present study) examined period. This further highlights the need to address the increased challenges in the application of the method (Steenkamp and Northcott, 2007; Beck et al., 2010).
} 
quantitative technique or it could further take a qualitative form. This is in essence a pseudo-dilemma, given that, "[u]ltimately all reading of texts is qualitative, even when certain characteristics of a text are later converted into numbers" (Krippendorff, 2013, p. 22). Behind these arguments however, are some fundamental distinctions made on the different forms of content that are of concern to content analysts (Potter and LevinDonnerstein, 1999). As Krippendorff (2013) points out, over the years scholars have provided essentially three kinds of definitions of the method:

1. definitions considering content to be contained in a text;

2. to be a property of the source of a text;

3 . or to emerge in the process of a researcher analysing a text relative to a particular context.

An example of the first kind is Berelson's (1952, p. 18) definition of content analysis as "a technique for objective, systematic, and quantitative description of the manifest content of communication”. Proponents of such a view (e.g. Lasswell, 1949; Deese, 1969) emphasise that it should be a systematic, objective and generalisable approach where quantification is an essential feature. To ensure that these criteria are met, theorists further argue for a focus on the manifest (the 'surface') rather than the latent (deeper) meaning of the text and primarily to the syntactic (combinations of signs without regard for meaning) dimensions of communication, which are easily observable. This rather 'mechanistic' view (Merkl-Davies et al., 2011) has also been inferred as form-oriented, due to its focus on the "routine counting of words or concrete references" (Smith and Taffler, 2000, p. 627) and would involve generating categories from previous literature. Categories can either be standard (to facilitate comparative and cumulative research) or custom (to better reflect the problem at hand) (Holsti, 1969). All these approaches however, have been criticised as being too narrow, producing potentially misleading inferences (Stone et al., 1966).

Researchers have, as a consequence, often turned their attention to the latent content. Given the plethora of the meaning-oriented approaches however, a further distinction needs to be made based on whether the focus is on the semantic (meaning of signs) or the pragmatic (the relationship between the communication symbol and its user) dimensions of communications. A definition focusing on the semantic aspect is this early one offered by Krippendorff (1969, p. 11) considering the method to be "the use of replicable and valid methods for making specific inferences from text to other states or properties of its source". Although such a definition seemingly removes the quantification pre-requisite, precedence is still given to content and objective patterns are sought to be uncovered by sorting and recognising the connections among symbols (Potter and Levin-Donnerstein, 1999). Most approaches, therefore, would still be expected to have a predominantly quantitative orientation. Categories would be typically deduced from theory but, subject to the degree that the underlying data have contributed in their development, they can also be inferred as abductive (this involves the development of categories during an iterative process of going back and forth between the theoretical concepts and the data (Merkl-Davies et al., 2011))

The third type of definitions acknowledges the researcher's own conceptual contribution to the reading of a text and relevance to the analysis. This later definition by Krippendorff (2013, p. 24), considering content analysis to be "a research technique for making replicable and valid inferences from texts (or other meaningful matter) to the 
contexts of their use", is an example focusing on the pragmatic communication aspect. Proponents of this view would support the development of inductive categories based on some type of thematic analysis of the text, although abductive categories may also be employed subject to the degree that existing theory is considered, as explained above. However, and in addition to being accused of being more subjective and unreliable (Lasswell, 1949), a further major limitation of such a wide approach is that it is difficult to develop a definition for it (Barcus, 1969) and identify conditions that differentiate it from other systematic forms of interpretive or critical analysis without considering it as a 'universal' meaning-oriented technique of message analysis, encompassing all the rest. For example, Krippendorff (2004) seems to consider discourse; social constructivist; rhetorical; ethnographic; and conversation analyses as types of qualitative content analysis as they all involve some analysis of content.

These arguments are associated with the wider epistemological debates of positivism vs. interpretivism and quantitative vs. qualitative methods (Sepstrup, 1981; Merkl-Davies et al., 2011) and in many respects are not incompatible (Weber, 2004). Indeed, a number of prominent theorists acknowledge that "approaches and methodologies are never good per se; they are good for something" (Rosengren, 1981, p. 14 , emphasis in original) and recommend the use of mixed methods for more complete inferences (see e.g. Pool, 1959; Holsti, 1969; Krippendorff, 2013). Such mixed approaches may e.g. include the generation of inductive categories with subsequent quantified coding or the parallel conduct of approaches focusing on the manifest and the latent content of the text, for triangulation purposes.

Although theorists comprehensively discuss specific aspects of (what they perceive to be) content analysis, they rarely attempt to identify a broader framework, incorporating alternative types. Table 1, which primarily draws on Potter and Levin-Donnerstein (1999) and Krippendorff (2013), synthesises their arguments and attempts to provide a wider typology, based on the foregoing discussion. These distinctions are certainly not clearcut; for example, when attempting to investigate the latent content some manifest is also likely to be considered and as Rutherford (2005, p. 351) argues, the difference between form- and meaning-oriented content analysis "is one of degree rather than kind" (MerklDavies et al., 2011). Furthermore, similarly to the meaning-oriented, a number of further distinctions among the form-oriented approach can also be made, mainly based on the degree of quantification or the specific field characteristics (Deese, 1969; Holsti, 1969). Due to the primarily quantitative orientation of the method in SER research and the apparent vagueness in defining the meaning-oriented approach embracing the pragmatic communication aspect, this paper focuses on the more restricted view of the method, considering the syntactic and semantic aspects.

\section{Table 1 about here}

As the table illustrates, there are also differences across the role of theory among these distinctions ${ }^{3}$. Theory may be a) inductively generated; b) used as a basis to deduce

\footnotetext{
${ }^{3}$ Although it could be argued that all research, and indeed all human activity, is theory driven, as "we all use theories in our everyday lives to make sense of the world in which we live" (Oats, 2012, p. 9), in this paper, similarly to Potter and Levin-Donnerstein (1999) the word theory is used to denote explicit (i.e. 'formal') theory. As such, it has been defined by Strauss and Corbin (1998, p. 22) as "a set of welldeveloped categories (e.g., themes, concepts) that are systematically inter-related through statements of relationship to form a theoretical framework that explains some relevant social, psychological, educational, nursing, or other phenomenon". By using such theories to help to explain phenomena and by contributing
} 
coding schemes; or c) even play no role. Once a decision is made on the role of theory in analysis, "it becomes much clearer what the role of coders is to be" (Potter and LevinDonnerstein 1999, p. 259). Typically form-oriented studies do not have a role for theory in designing the analysis. As only the manifest content needs to be coded, designers do not need to prepare advanced coding decision protocols and a mere definition of what is sought to be coded may be adequate, particularly when e.g. the presence or absence or the frequency of occurrence of specific information is recorded. Theory may, nevertheless, have a supplementary role i.e. not be used as a basis for coding but potentially later assist in explaining the findings.

Meaning-oriented studies considering the semantic aspects typically rely on a deductive role of theory, unlike studies focusing on the pragmatic aspects that generate codes inductively and overall "cherish open-endedness" (Krippendorff, 2013). Achieving objectivity is more difficult for studies coding latent content than those coding manifest. Semantic studies designers, therefore, need to develop more comprehensive theory-based coding protocols to guide judgments. It is also important when more subjective judgments (i.e. beyond those agreed in protocols) are made, these to be shared across coders, to ensure that "the meaning therefore is also likely to reach out to readers of the research" (Potter and Levine-Donnerstein, 1999, p. 266).

Having outlined some broad varieties of content analysis, the next section details how this review was conducted.

\section{The method}

The collection and review of the relevant papers was quasi-systematic. Systematic reviews of the literature are not frequently employed in the SER research to date (but see Marr et al., 2003; Walker, 2010, for explicit, and Deegan, 2007; Deegan and Soltys, 2007; Thomson, 2007, for implicit, attempts). However, this distinct methodological approach (Glasziou et al., 2001; Bryman and Bell, 2007) is well established in the health care research (e.g. Egger et al., 2001; Jefferson et al., 2003; Price et al., 2004). The purpose of a systematic literature review "is to evaluate and interpret all available research evidence relevant to a particular question" (Glasziou et al., 2001, p. 1), and with regards to data collection this either involves detailed keyword searches (as in Marr et al., 2003) or exhaustive reviews of selected publications (as in Deegan, 2007; Deegan and Soltys, 2007; and Thomson, 2007). In either case, a completed review should consolidate what is known and identify any gaps in current knowledge leading to a more reliable and accurate picture of the current state of the field literature (Price et al., 2004).

The collection of papers combined the above approaches and took place in several stages. Firstly, an exhaustive review was conducted of all the volumes to date (December 2013) of seven of the most prolific in publishing SER work journals, as identified by the Centre for Social and Environmental Accounting Research (CSEAR), "arguably the leading international centre for research into social and environmental accounting" (Deegan and Soltys, 2007, p. 75), presently located at the university of St. Andrews, UK. These are: Accounting Forum; Accounting, Organizations and Society; Accounting, Auditing and Accountability Journal; Critical Perspectives on Accounting; Journal of

to the development of theories, researchers are able to contribute to social science more widely (Oats, 2012). 
Business Ethics; Social and Environmental Accountability Journal; and Sustainability Accounting, Management and Policy Journal. Secondly, all journals listed in the UK Association of Business Schools' (ABS, 2010) Academic Journal Quality Guide, under the 'Accountancy' and the 'Business Ethics and Governance' headings, were identified and scanned for relevant articles using keywords, such as 'content analysis' and 'social/environmental disclosure'. Selected journals under the 'General Management', 'Organization Studies', 'Public Sector Management' and 'Social Science' headings as well as some journals that are not listed, but are also identified by CSEAR and Deegan (2007), Deegan and Soltys (2007) and Thomson (2007) as publishing SER papers, were also keyword-searched for relevant papers ${ }^{4}$. Thirdly, the reference lists of previously conducted methodological reviews of content analysis in SER (Guthrie and Mathews, 1985; Gray et al., 1995b; Hackston and Milne, 1996; Milne and Adler, 1999; Unerman, 2000; and Steenkamp and Northcott, 2007) were scrutinised and all referenced studies available through the authors' library were collected and reviewed.

The data collection resulted in 251 papers to be identified. The time frame (1974 2013) covers the apparent (so far) climax of SER (Milne and Gray, 2007) and is generally consistent with other relevant studies (i.e. Erusalimsky et al., 2006; Guthrie et al., 2008). Similarly to all aforementioned systematic reviews of the literature (and particularly given that data collection heavily relied in keyword searches), it should also be acknowledged that "this sample of literature is far from complete" (Thomson, 2007, p. 19). Furthermore, as only research papers published in academic journals have been considered, the various SER textbooks, research reports and monographs have therefore been ignored. It was expected, however, similarly to Deegan and Soltys (2007) that the sample "should provide some guide - albeit imperfect - about the relative extent of social accounting research [employing content analysis, and that] ...it should provide an insight into the general trends in the research" (p. 76).

Systematic reviews of the literature are usually followed by some form of metaanalysis (Glasziou et al., 2001). Meta-analysis most often takes a quantitative form and it "involves summarizing the results of a large number of quantitative studies and conducting various analytical tests to show whether or not a particular variable has an effect" (Bryman and Bell, 2007, p. 101). However, although it is often thought of metaanalyses as employing mathematical techniques for comparing, synthesising, and analysing results of multiple studies (as it is also generally the case in accounting and management research, see e.g. Borkowski, 1996; Geyskens et al., 2009; Ahmed et al., 2013), "statistical techniques are not a necessary feature of such reviews" (Schwandt, 2007, p. 266). Also referred to as qualitative research synthesis (Savin-Baden and Howell Major, 2010), and meta-ethnography (Bryman and Bell, 2007), qualitative meta-analysis is a distinctive category of synthesis in which the findings from completed qualitative studies in a target area are formally combined (Lewis-Beck et al., 2004). The approach

\footnotetext{
${ }^{4}$ The widely widely-used ABS journal guide has been recently criticised for explicit and implicit subject bias in the compilation of journal rankings (Gray and Hoepner, 2011; Hoepner and Unerman, 2012). However, in this paper the guide is primarily used as a detailed list of journals, which potentially publish, or not, SER studies. Journals that are not listed in the guide but are designated by CSEAR as publishing SER papers have also been considered, in line with Deegan (2007), Deegan and Soltys (2007) and Thomson (2007).
} 
requires adhering to a methodological, rigorous process while at the same time striving for transparency (Savin-Baden and Howell Major, 2010).

In this paper, similarly with the cited systematic reviews of the SER literature, qualitative meta-analysis is employed. This is primarily due to the methodological focus of the paper, but also because of the identified enormous variety of content analysis approaches and the method's frequent interpretive use in SER research, as also demonstrated in the findings section. The meta-analysis in this paper, nevertheless, took a more detailed form than the implicit attempts cited in the SER literature by employing an index, similarly to Riffe and Freitag (1997) and Duriau et al. (2007), who also developed indices to review the content analysis literature in the fields of journalism and mass communication, and organisation studies, respectively. Both studies' indices examined the research themes, sources of data, coding approaches and analytical methods used in their literature. This study also largely considers these areas albeit in greater detail and is more focused on the key methodological choices SER researchers face (such as e.g. deciding on categories and measurement, which are not considered by either study). The finalised coding scheme is therefore abductively generated, with reference to both Riffe and Freitag and Duriau et al. and the identified variations in the reviewed literature. Subsequent descriptive analysis taking a graphical and tabular form is then utilised and an interpretive account is developed to explain the identified variations, similarly to Volkens' (2007) meta-analysis of content analysis in the field of electoral studies.

Details of the papers reviewed and the coding scheme used are not provided for word saving purposes but are available from the authors upon request. The first author coded all the articles. To ascertain reliability for the coding procedures coding was repeated for 30 papers and two stability scores (Pearson's correlation coefficient and Cronbach's Alpha) were calculated. Both tests on average were above the .90 level and met reliability standards (Krippendorff 2013). The remainder of this paper discusses the study's findings.

\section{Validity challenges}

Figure 1 provides a graphical illustration of the number of sampled papers across the forty years investigated. It further distinguishes among the three main journal groups specified earlier: accounting; ethics, governance and wider management; and the (mainly accounting) journals currently not listed in ABS (2010). Evidently there is a considerable increase in the use of the method over the years, which to some extent can be explained by the increased academic interest in the field (Thomson, 2007). The increased academic interest could in turn be related to the increased organisational provision of SER over the same period (Milne and Gray, 2007; Guthrie et al., 2008). The increase in the use of the method is particularly evident in the ethics/management and unclassified journals. Given the small number of papers sampled in the first 20 years $(30$ i.e. 12\%), the subsequent trend discussion across methodological decisions and journal groups will focus in the period 1994-2013.

\section{Figure 1 about here}

Validity relates to how well the results of a study mirror reality (Jones and Shoemaker, 1994). Although a number of distinct validity types have been identified, and relative tests have been developed, in general establishing validity is regarded as a two-step 
process (Weber, 1990): firstly developing a coding scheme that measures what its user claims it measures (also referred to as face or internal validity); and secondly ensuring that the inferences drawn are compelling and are able to inform successful actions i.e. be generalised (also referred to as external validity). In developing coding schemes, researchers need to mainly decide on the sources to be analysed; the body of content examined and classification schemes employed; and the quantification type (what Krippendorff, 2013 respectively refers to as sampling units, context units and recording [or measurement] units), which may all impact validity. The findings on these decisions are discussed in detail next, following a consideration of the identified research themes in the sample.

\section{Research themes}

A major obstacle when attempting to explore the use of content analysis in SER is that both concepts do not have widely accepted definitions. As it seems particularly challenging for researchers to decide what is and what is not SER (Gray et al., 1995), it could be argued that almost all (particularly volumetric) SER research is meaningoriented. Nevertheless, and despite the difficulty in developing a definition and appropriate decision protocols, most research attempting to capture the surface communication content, which is usually the disclosure topic (but could also concern e.g. the monetary or declarative nature of information), would still qualify as form-oriented. This is particularly given that, once researchers agree on what is SER, deciding on a specific topic tends to be a rather straightforward task (Milne and Adler, 1999) ${ }^{5}$. Table 2 summarises the key findings from the index analysis, with reference to form and meaning oriented variations. Given the identified variety of research themes, it was decided to note them in an open-ended way, to allow for the plurality of topics to be revealed.

\section{Table 2 about here}

Form-oriented designs have a strong presence in the literature. They appear to be mostly exploratory, attempting to identify disclosure types and trends across countries, industries or individual organisations. The literature has offered significant insights into the SER patterns of organisations domiciling all over world, in developed countries such as Australia (Kelly, 1981), Germany (Dierkes, 1979); UK (Campbell et al., 2003) and Japan (Yamagami and Kokubu, 1991) but also developing ones, such as Indonesia (Gunawan, 2007), Malaysia (Sawani et al., 2010) and Mauritius (Mahadeo et al., 2011). Given that approximately $38 \%$ of these studies are longitudinal, insights were gained also into how disclosure varied over time: a general upward trend was noted (but with variations in proportions) and relevant explanations were produced.

Industry disclosure patterns were also revealed, by studies either comparing SER across industries (Cambpell et al., 2003) or by focusing on single industries, such as the food and beverage (Guthrie at al., 2008) or the mining (Magness, 2010, Coetzee and van

\footnotetext{
${ }^{5}$ Research was therefore classified as form/meaning oriented based on the types of categories used. Studies solely analysing the topic of disclosure and/or whether or not this is of monetary form, were considered to be form-oriented. In contrast, studies employing (all remaining) classifications, which more explicitly explore the latent content, were classified as meaning-oriented. Although arguably an alternative way to classify studies would be based on subsequent interpretation, in this study the classification is based on the orientation of the coding instrument itself, not on subsequent interpretation of findings. Nevertheless, inductive and abductive classifications (which in the sample exclusively concerned the topic of disclosure) were also considered to be meaning-oriented.
} 
Staden, 2011). Other exploratory studies have attempted to assess the disclosure tone (e.g. Cho et al., 2010) or, more often, medium. Studies increasingly look at the web (e.g. Esrock and Leichty, 1998; Patten and Crampton, 2004; Rowbottom and Lymer, 2009) and reveal differences in disclosure across media, with a generally finding being that e.g. only a fraction of SER is disclosed in the annual report (Zeghal and Ahmed, 1990; Unerman, 2000). Studies have also explored the quality (Wiseman, 1982; Hasseldine et $a l ., 2005)$ and objectivity in reporting and have exposed the organisational tendencies to provide inaccurate representations of their environmental performance to retain a positive image (Deegan and Rankin, 1996).

Form-oriented analyses also attempt to identify determinants/relations of disclosure. For example often the relation of disclosure with economic (Belkaoui and Karpik, 1989) and environmental performance (Ingram and Frazier, 1980; Buhr, 1998; Patten, 2002b) is sought to be examined with the findings being inconclusive. In addition the literature has reported statistically significant relationships of SER with a number of corporate characteristics, such as size and industry (Cowen et al., 1987; Gray et al., 2001; Gao et al., 2005). Often this strand of literature employs advanced statistical analysis to ascertain relationships and does not explicitly employ a theoretical framework but rather sets hypotheses based on previous relevant studies. Although theory is not used as a basis for coding, references to particularly legitimacy and stakeholder theories are frequently made to explain findings and their explanatory power is often tested using mainly longitudinal designs (Deegan et al., 2000; 2002).

Meaning-oriented research is also primarily exploratory (41\%), but has also frequently employed content analysis to explain the possible motivations behind managers' voluntary decisions to take such action, generating seminal findings. Out of the 251 papers reviewed, 146 papers explicitly employed an explanatory theoretical framework in their study, with $70(29 \%)$ using legitimacy theory. Other frequently used frameworks include stakeholder theory (27 papers) and institutional theory (11 papers), whilst a wide array of alternatives was noted (15\%). Many of the papers not explicitly using a theoretical framework still utilise notions used by a number of theories, such as stakeholder, image, or public pressure (e.g. Esrock and Leichty, 1988).

Although explanatory designs have often related disclosure to media (Brown and Deegan, 1998; Deegan et al., 2002; Patten, 2002a), they have most frequently attempted to reveal motivations through longitudinal case studies and qualitative-focus research frames. Indeed longitudinal designs are more frequent in meaning-oriented studies (62\%). Content analysis has also contributed towards identifying specific disclosure strategies used by organisations operating mostly in developed (Cormier and Gordon, 2001) but also within developing countries (Islam and Deegan, 2010) and has further examined compliance to social and environmental standards, such as GRI (Turner et al., 2006).

Often the borders among form- and meaning-oriented distinctions are blurred. For example, Cho et al.'s (2010) attempt to assess disclosure tone by particularly identifying some theoretically rooted in impression management keywords and employing relevant software to generate relevant scores would be difficult to classify. Frequent attempts to assess the 'quality' of content by classifying it as general/specific or hard/soft would also rather be considered as 'borderline' meaning-oriented. Such evidence lends support to Rutherford's (2005) argument of the difference between approaches being one of degree rather than kind. Nevertheless, despite the manifest or latent orientation of the reviewed 
papers, and that these often investigate similar research questions, an enormous diversity of content analysis designs was noted across all key decisions, which is explored next.

\section{Sampling units}

Sampling units "are units that are distinguished for selective inclusion in an analysis" (Krippendorff, 2004, p. 98) and they refer to the data sources used. Validity in sampling mainly refers to the degree to which a population is accurately represented in the sample. Most form-oriented analyses, and meaning-oriented employing deductive designs, typically focus on larger samples and thus need to use appropriate sampling plans to ensure that the units sampled do not bias the answers to the research question (Krippendorff, 2013). Analyses employing smaller samples (or even the entire population) still need to ensure though that these are suitable to the content and theory choices.

Researchers seem to be largely consistent in their sampling decisions. A great number of papers $(76 \%)$ used annual reports as their (most often, exclusive) sampling unit. Other frequently used sources included stand-alone SER publications (such as environmental or social reports, 26\%) and the internet (14\%), although sources such as codes of ethics, brochures and specific databases were also employed. Media articles, questionnaires and interviews were also employed, albeit more often not as prime content analysis sources but as supplements to the analysis. As Figure 2 shows, unsurprisingly annual reports are primarily used in articles published in accounting or unclassified journals, whereas ethics and management papers seem to generally employ a more diverse range of sources. A number of reasons for the widespread use of annual reports have been put forward in the literature. The annual report is the most widely distributed of all public documents produced by a company (Savage et al., 2000) and they are perceived to be the single most important source of information on corporate activities (Adams et al., 1998).

\section{Figure 2 about here}

Employing almost exclusively annual reports considerably benefits the comparability of the findings but raises concerns over the quality of the inferences drawn as these are not the only medium through which companies report their social, environmental or ethical behaviour, a view empirically supported by Unerman (2000), Frost et al. (2005) and Guthrie et al. (2008). As a consequence, a number of studies now increasingly employ sources in addition to or other than the annual reports as sampling unit. As Figure 2 shows, there is indeed an evident trend across all journal groups to employ additional sources. It should be noted, nevertheless, that it is almost impossible to identify all corporate communications that could possibly contain SER information (Guthrie et al., 2004) and it thus seems similarly impossible to identify all the SER activities of the examined organisations.

\section{Context units and categories}

Context units are defined by Berelson (1952, p. 135) as "the largest body of content that may be examined in characterizing a recording unit". Unlike sampling units, which appear to be a widely accepted and undisputed term in the SER literature, "much of the discussion on the 'unit of analysis' confuses the issues of what should form the basis for coding with what should form the basis for measuring or counting the amount of 
disclosure" (Milne and Adler, 1999, p. 243). Part of this confusion may be generated from the use of different and at times opposite terms from researchers (e.g. Milne and Adler's, 1999, coding units are what Krippendorff, 2013, describes as context units, whilst Milne and Adler's measurement units are Krippendorff's recording/coding units). In this paper, Krippendorff's (2013) terminology is adopted, in accordance with a number of other prominent theorists (Berelson, 1952; Osgood, 1959; Stone et al., 1966; Weber, 1990).

There seems to be no logical limit for the size of the context units. Particularly in form-oriented analysis, context units as small as sentences could be used for individual words. But in meaning-oriented studies, when e.g. decisions on a positive or negative context of a commentary are made, "analysts might need to examine even larger context units, such as a paragraph or a whole speech" (Krippendorff, 2004, pp. 101-102). Naturally researchers need to clearly 'define' their context units (i.e. formulate appropriate categories) before commencing recording them. Abbot and Monsen (1979, p. 506) seem to consider a prominent type of error to be "the formulation of categories that do not reflect all the issues actually contained in the report that are of policy interest". As Holsti (1969, p. 95) points out, "categories should reflect the purposes of the research, be exhaustive, be mutually exclusive, independent, and be derived from a single classification principle" (emphasis in original). Establishing clarity in definitions and coding procedures seems to be a prerequisite for attaining validity (and reliability, as discussed later) for the coding schemes, both form and meaning oriented.

Form-oriented studies typically draw categories from relevant literature and either employ them per se or customise them to the set research objectives. The subject of disclosure is the most common contextual distinction in the sample (all bar one reviewed studies employed it and in most $-57 \%$ - it was the only classification used). In the SER literature, four major subject categories are employed: marketplace (consumers, creditors), workplace (employees), community, and environment, but there will always be a need for a development of an 'other' category (Gray et al., 1995b). Categories seem to be predominantly generated deductively: $89 \%$ of all articles adopt a deductive design (usually customising existing categories in the literature) and very few explicitly generate categories inductively or abductively. Subject categories varied in detail, ranging from 4 (Tilling and Tilt, 2010) to 95 (Clarkson et al., 2008)! Most papers seem to therefore adjust their categories to the set research objectives: e.g. Tilling and Tilt's categories are the only common disclosed themes over the 43 years of their case study whilst Clarkson et al.'s reflect their attempt to better capture environmental disclosure and relate it to economic performance. Holsti (1969, p. 95) considers "reflect[ing] the investigator's research question... the most important requirement of categories" and warns that "[u]nless theory and technique are intimately related, even the minimal requirements of [internal] validity cannot be met" (p. 94). However, these customisations (also evident in the reporting and sampling decisions) are detrimental for the comparability of findings and are not always essential, particularly when they are made at the manifest level. When wider SER surveys investigating disclosure patterns are conducted, researchers could employ previously used categorisations in the literature and could highlight any deviations (due to e.g. country, industry, or timing factors), directing other researchers to examine comparable effects in other settings, in order to ascertain meaningful 
comparisons and cumulative research (Lasswell, 1949; Berelson, 1952) and meet the external validity requirements.

Internal validity is therefore often in conflict with external: the former would prioritise formulating categories that reflect the underlying text whereas the latter would prioritise relevance and comparability to other cumulative research. Internally valid findings may not always be externally useful. Ascertaining external validity implies the existence of a standard that serves as a basis to compare findings. There is an absence however to date of such 'standardised' volumetric or index subject categories, a problem largely stemming from the variety of definitions of the field, that are "generally too exclusive... or too all-embracing" (Gray et al., 1995, p. 89) ${ }^{6}$. Setting such a standard objectively would be expected to be easier when the manifest content is analysed rather than the latent.

In meaning-oriented approaches external validity can be potentially ascertained by looking at previous expert works and ensuring that the coding rules are correctly applied (Potter and Levine-Donnerstein, 1999). In this sample, researchers usually employ additional categories in an attempt to assess the quality/evidence of the disclosure. Most frequently, the basic (form-oriented) quantitative vs. qualitative distinction (25\%) is used. Behind this evidence, there is the intent of researchers to identify whether companies disclose hard-fact, substantial information or not (the general vs. specific and hard vs. soft categories found in the sample also largely contribute to this end). However, a major limitation of this distinction is that it is not normatively rooted and it is not made clear whether all the quantitative information counted is of relevance (since e.g. some SER data maybe at industry level) or that all declarative statements are not substantive (as when awards are listed). Other employed distinctions with greater emphasis on the latent content are the positive vs. negative and the substantive vs. symbolic. Even though these distinctions generate more meaningful inferences, it is important to note that the greater focus on the latent content makes it more difficult to develop detailed decision rules, threatening the reliability of the analysis.

\section{Recording}

Recording (also referred to as measurement) units are defined by Holsti (1969, p. 116) as "the specific segment of content that is characterized by placing it in a given category". All reviewed papers could be considered as following either an 'index' or a 'volumetric' design. Index studies generally check for the presence or absence of specific items of information (what Stone et al., 1966, describe as 'contingency analysis') whereas volumetric check for the overall volume of disclosure, most frequently by counting

\footnotetext{
${ }^{6}$ The variety of SER definitions is also reflected in the considerable variety of titles that organisations have used over the last years to term their stand-alone reports. Erusalimsky et al. (2006) consider this diversity to suggest "a far from homogeneous response to whatever it is that is driving this voluntary reporting" (p. 13) and stress that this fluidity in terms allows organisations to have more discretionary space and ultimately influence "the terms of debates on sustainability, social responsibility and the future of mankind" (p. 19). Researchers nevertheless have also used heterogeneous terminologies to refer to the field (often picking out, or combining, the terms 'social'/'environmental'/'ethical'/'sustainability'/'responsibility' with the terms 'accounting'/'reporting'/'auditing'/'disclosure'). This could be attributed inter alia to diverse research objectives, publication trends, journal terminologies, and specialised funding calls and it is arguably also rooted in the field's general lack of regulation (but see Adams and Narayanan, 2007; Adams and Petrella, 2010, for discussions of some recent attempts for standardisation, albeit of voluntary nature).
} 
words, sentences or proportions of an A4 page. Overall $72 \%$ of the studies employed an index approach and $40 \%$ a volumetric one. More specifically, $60 \%$ employed an index measure only; $28 \%$ employed a volumetric measure only; and $12 \%$ employed combinations of the two. Although form and meaning oriented approaches are compatible with both volumetric and index types, these need to be correctly specified to increase internal validity (Jones and Shoemaker, 1994) and also need to be comparable to strengthen external validity. As Table 2 shows, index approaches are particularly popular in form-oriented studies, whereas volumetric are more frequent in meaning-oriented studies. Index studies are predominating in ethics and management journals, whereas accounting journals publish a comparatively greater proportion of volumetric studies, as Figure 3 illustrates.

\section{Figure 3 about here}

Index studies appear to be most commonly labelled as content analysis, as opposed to the 'line', 'sentence' or 'page counts' terms generally attributed to the volumetric approaches (see e.g. Abbott and Monsen, 1979; Wiseman, 1982; Patten and Crampton, 2004). As Table 2 illustrates, most frequently (47\%) a simple binary coding scheme is used, where a score of 1 or 0 in the presence of absence of the item is respectively attributed. At times, the aggregated frequency of the presence of these items is further estimated (26\%). Index studies, though, may further incorporate ordinal measures, to allow for the quality of the specific disclosure to be assessed (Beattie et al., 2004), with most notably Wiseman (1982) employing a four-level index (quantitative SER=3, nonquantitative $=2$, general $=1$, absent $=0$ ).

In volumetric approaches, on the other hand, it is assumed that the extent of disclosure can be taken as some indication of the importance of an issue to the reporting entity (Krippendorff, 2013). Although, clearly not all the measured information would be of the same type or quality (Guthrie and Mathews, 1985), this can be assessed by applying a wide range of (particularly latent) categories. Considering the evidence that SER has been increasing across time, both in number of disclosing companies and in the amount of information being reported (Milne and Gray, 2007; Guthrie et al. 2008), a number of researchers are employing volumetric approaches in order to get a proxy of the emphasis given to particular content categories (Milne and Adler, 1999) rather than simply checking for the presence or absence of specific disclosure. They often justify their choice on the empirical evidence (Grey et al., 1949; Patten, 1992; Deegan and Gordon, 1996; Deegan and Rankin, 1996; Hackston and Milne, 1996; Campbell, 2000) which gives support to the suggestion "that measurement error between various quantification techniques is likely to be quite negligible" (Milne and Adler, 1999, p. 243). It should be noted however that this evidence comes from studies that seemingly only consider narrative reporting and the suggestion, therefore, would not be expected to hold true when pictorial evidence is additionally considered. As Table 3 illustrates, each unit has its distinct advantages and disadvantages, which need to be considered when selecting them and interpreting results.

\section{Table 3 about here}

Among the 101 volumetric papers identified in the sample, 24 use words, 39 sentences and 32 standardised A4 and/or page-size approaches as recording units (characters, themes, lines and phrases have also sporadically been used). The main benefit of using words and sentences appears to be that they are not affected by variations 
in the font size, or by the presence of margins/blank pages, or by whether the sources are in an electronic or printed form and they generally seem to lend themselves to a more controllable analysis (Gao et al., 2005). A strong argument, however against employing either words or sentences as recording units is that this will result in any non-narrative information (such as images) being ignored (Unerman, 2000). In an attempt to capture this valuable information and increase the validity of inferences, researchers may employ either 'standardised' (i.e. grids taking the space of an A4 page) or 'page size' proxies (i.e. grids considering the collected data in conjunction with the physical source from which they are extracted). These gains in validity however may come at the expense of reliability (Steenkamp and Northcott, 2007)

Importantly, Figure 3 also highlights the increasing use of index designs, and the decreasing use of volumetric approaches, in the last 15 years across all journal groups. When seen along with Figure 2, and considering the developments in organisational provision of SER over the forty-year period examined, one could arguably distinguish three periods in content analysis research. In the first period, from 1970s till around mid1990s, when organisational and academic interest in the field was scarce, given the small disclosure volume researchers were primarily interested in capturing the extent of disclosure and were therefore primarily using simple, binary index approaches. In the second period from mid-1990s till around 2000, academic research became more systematic and by acknowledging the increased relevant organisational disclosure, it also started more frequently employing volumetric approaches, in order to capture the full intensity of the phenomenon. Indeed, a number of academic papers were published at the time (Gray et al. 1995a,b; Hackston and Milne, 1996; Milne and Adler, 1999; Unerman, 2000) encouraging researchers to employ detailed volumetric approaches and analyse a wider than the annual report array of sources. However, the subsequent explosion in organisational provision of SER, along with the relative ease in accessing this information, primarily through the internet, probably forced researchers to go back to employing (the easier to use and quicker) index approaches, albeit in an increasingly more complex, weighted form, to better capture quality.

This pragmatic shift of interest to some extent is plausible given the research need for capturing SER to its full extent. However, as it is argued in the next section this may have also impacted reliability.

\section{Reliability challenges}

Reliability refers to the extent to which studies can be replicated. It requires that a researcher using the same methods can obtain the same results as those of a prior study (LeCompte and Goetz, 1982). Krippendorff (2013) identifies three types of reliability in content analysis, these being stability (estimating the extent to which a measuring procedure yields the same results on repeated trials), reproducibility (the extent to which the same results are achieved by independent coders) and accuracy (assessing deviations from a set coding standard). Given the lack of widely-accepted SER coding standards, researchers may find it hard to apply the accuracy test to their interrogation instrument (Guthrie and Mathews, 1985) and they should hence focus on estimating the other two tests. In practice, most reproducibility tests (such as simple percent agreement or more complex Scott's Pi, Cohen's Kappa, Fleiss' revisited Kappa and Krippendorff's Alpha) can also be employed to assess stability, as they require a minimum of two sets of 
observations (i.e. relevant software do not distinguish whether the additional set of observations comes from a different coder or is a retest).

Given the identified in the literature increasing use of form-oriented, and particularly custom, categorisations, it would be expected studies to apply particular care in ascertaining reliability for the coding procedures. This is because the coding is oriented toward capturing the surface features of the content and reliability is thus seen as "necessary precondition for validity" (Potter and Levine-Donnerstein, 1999, p. 272). More than half of the papers $(55 \%)$ however make no mention at all to reliability checks, about a quarter (27\%) discuss reliability but without providing a score as an indication and only 47 papers $(18 \%)$ provide a reliability estimate. It is interesting to note that meaning oriented studies in the sample appear to be more reliable than form-oriented. This is a paradox, considering the comparatively increased subjective judgements involved in meaning-oriented analysis (Potter and Levine-Donnerstein, 1999; Steencamp and Northcott, 2007). Overall, the findings are in contrast to both Riffe and Freitag (1997) and Duriau et al. (2007), who respectively found that 56\% of the journalism and mass communication, and $62 \%$ of the organisation studies', content analysis studies report reliability scores. As Figure 4 illustrates, the lack of reliability checks is evident throughout the sampled journal groups, although accounting journals seem to comparatively include more frequent reliability discussions.

\section{Figure 4 about here}

Figure 4 provides further support to the 'three-period' argument expressed earlier. Evidently in the first twenty years reliability checks were uncommon, whereas in the mid to late 1990s they became much more frequent. However in the last 15 years reliability checks have become more infrequent proportionately. Although this trend could be evidently associated with the aforementioned changes in the sampling and recording units, it should be mentioned that reliability primarily concerns the contextual classifications used (i.e. irrespective of the recording or sampling decisions, researchers need to assess the reliability of the coding schemes). However, very few studies also include illustrative examples or provide coding protocols, which limits the guidance offered to future researchers and those wishing to compare studies. Although the latter observation could be potentially attributed to journal restrictions, the apparent researcher reluctance to take reliability tests could perhaps to some extent be further linked to two more observations from the reviewed sample of studies on the use of computerised analysis and on interpretation of findings.

An astonishingly small number of papers (3\%) seem to employ computerised approaches. A variety of software has been used, including WORDS (Tennyson et al., 1990), NVivo (Bell and Bryman, 2007), Lexico 3 (Ortiz-Martinez and Crowther, 2008), Diction (Cho et al., 2010; Payne et al., 2011), SPAD-T (Albertini, 2013). Most papers deductively select words or dictionaries to explore the language and verbal tone used in reporting, although interestingly Bell and Bryman (2007) use their programme to inductively generate codes before estimating the frequency of their occurrence. Some papers used software to locate disclosure before manually coding (Walden and Stagliano, 2003; Haddock-Fraser, 2012; Bodolica and Spraggon, 2013) or to verify manual word counts by copying environmental information from an electronic file, to ensure consistency in measurements (Wilmshurst and Frost, 2000). The limited use of computerised approaches could perhaps be attributed to the inherent difficulties in 
measuring and classifying information in reports in pdf, printed or any other form. Computerised approaches can nevertheless bring several advantages to research with regard to inter alia time, cost and data management, which can greatly enhance the use of the method (Duriau et al., 2007). They can particularly enhance reliability, and allow for wider sources to be considered and for more sophisticated quantitative analyses to take place $^{7}$.

As regards interpretation of findings, as Table 2 and Figure 5 illustrate, the majority of studies (52\%) in the sample seem to employ advanced quantitative analyses. A considerable number of studies, throughout the journal groups, nevertheless only conduct descriptive analysis or complement it with some qualitative analysis. This suggests that there is a strong 'interpretive' orientation of many researchers using the methods, which can explain to some extent the reluctance to engage with reliability checks and computerised software, in the fear of losing context. Nevertheless ascertaining reliability for coding procedures is imperative, particularly for form-oriented approaches, as this strengthens not only the comparability but also the internal validity of findings. Employing computerised approaches could also be beneficial for both qualitative and quantitative types of research as it is further discussed in the next section.

\section{Figure 5 about here}

\section{Implications of findings}

Content analysis has significantly contributed to SER research to date and with the increasing availability of computer tools and archived, on-line texts the scope for its further application seems vast (Cowton, 1998). By critically reviewing 251 published papers employing content analysis, the present study contributes to the literature in two ways: a) it provides a comprehensive review of the theory and practice of content analysis in SER research, with particular reference to implications for validity and reliability; and b) it describes changing patterns in content analysis, in order to help researchers "see the progress that has been made in achieving appropriate levels of rigor, and how they might contribute to continued progress" (Riffe and Freitag, 1997, p. 880).

The trend analysis indeed demonstrates some positive developments in the use of the method in SER research, particularly concerning the wider array of media examined and classification schemes use, with reference to specific journal groups. On the other hand, the foregoing discussion further highlights some outstanding issues of concern, pertaining to both validity and reliability. Attaining absolute validity and reliability would clearly be an impossible goal for any research effort (LeCompte and Goetz, 1982). As Riffe and Freitag (1997) relatively note, "it is far too easy to criticize decisions that researchers have made, often for the most legitimate of reasons" (p. 880). However content analysts need to approach these objectives by conscientiously balancing the various factors enhancing credibility within the context of their particular research problems.

The complete lack of standardisation in the coding procedures is of great concern. In theory, all the distinctions discussed can be standardised, as long as there is increased

\footnotetext{
${ }^{7}$ It should be noted that studies employing software do not often discuss reliability. This is because of the general assumption that coding procedures are perfectly reliable (Cho et al., 2010; Albertini, 2013). Nevertheless, reliability assessments could still be provided to demonstrate agreement among researchers on the suitable words/dictionaries used (Payne et al., 2011).
} 
transparency to ensure 'shared meanings'. However in practice, an enormous diversity is evident as regards categories, decision rules, definitions and even measurement approaches, undermining the comparability of findings and the accumulation of knowledge. Researchers most often justify their 'customisations' on the nature of their objectives, although journal length restrictions are also responsible for the lack of comprehensive discussions of decision rules. Researchers though need to be more reflective about the nature of their research (Oats, 2012) and accept that objectives, most times, are not poles apart and do not warrant such an enormous diversity. As regards the subject of disclosure, perhaps Gray et al.'s (1995) categories could be a useful base for volumetric works, whilst GRI (2013) seems to be the natural choice for index studies (indeed, to this end, a number of recent studies seem to refer to Clarkson et al.'s [2008] GRI-based categories, whilst many earlier ones have also referred to Gray et al.'s categories). LeCompte and Goetz (1982) have also noted that the comparability of studies may be reduced or obstructed by idiosyncratic use of initial analytic constructs. However, they suggest that "awareness of the participant derivation of the constructs may function as a control for threats to validity" (p. 51). Researchers, therefore, need to demonstrate deviations from the standard to strengthen external validity and allow other colleagues to investigate if these deviations are applicable in other settings.

The limited use of reliability assessments is also of concern, particularly given the decreased proportions noted in the recent years. Although it should be acknowledged that conducting (particularly reproducibility) reliability checks could be taxing for researchers applying the method manually, it needs once again to be stressed that ascertaining reliability for the coding procedures is imperative when form-oriented, or meaningoriented focusing on the semantic aspects, analyses are used, to ensure that coding errors are minimised and as accurate as possible findings are generated.

It is particularly concerning that (as also noted by Steenkamp and Northcott, 2007) very few studies seem to include illustrative examples and coding rules, which limits the guidance offered to future researchers and those wishing to compare studies. This could be related to the traditional brevity that journals often require in manuscripts (LeCompte and Goetz, 1982). Nevertheless, researchers need to be explicit about how subjective judgments are made so that they are transparent to others. As noted in Gray et al. (1995, p. 85), and is further stressed by Beattie and Thomson (2007), "the use of content analysis either demands, or at a minimum implies strongly, that the categories of analysis are derived by reference to shared meanings and that the data collection and analysis must be replicable". One strategy for illuminating areas of high subjectivity is to use multiple coders, who independently code a text, compare their results and reflect on their varying inferences and coding outcomes (Steenkamp and Northcott, 2007). Detailed coding rules may also be written, although spending too much time on developing reliability controls may shift attention away from the essence of the phenomenon of interest and thus harm validity (Potter and Levine-Donnerstein, 1999).

A greater adoption of computerised approaches in SER research is further recommended. These could assist both form-, and meaning-oriented analyses. Formoriented approaches, such as those identified in this study looking at disclosure tone and based on (theoretically-rooted or not) keywords could be very useful in measuring and comparing content although the practicalities of the particular nature of the data used should be acknowledged. As particularly Bell and Bryman's study has indicated (2007), 
qualitative analysis programmes may also assist in the analysis not only in terms of speed in coding but also bring in a number of validity benefits. Cross-code analyses can be conducted; data display matrices could be easily developed; further, since all the coded segments by a specific code can be retrieved, this means that more detailed and thorough coding decision rules can also be created through careful reviews; and perhaps more importantly, the program instantly measures the volume of textual information when the coding takes space, and can allow for a wider array of data sources to be considered (particularly now that most SER can be found in electronic form) and more reliable coding to take place.

Three main potential fruitful venues for further research may be identified. Firstly, a review focusing on the qualitative approaches subscribing to the broader content analysis view, including the distinct systematic ones, such as grounded theory and discourse analysis, could assist in clarifying their relationships and their potential contribution to SER. Secondly, a review of contemporary studies using the method in other fields and consideration of potential applicability to the SER practice, as in e.g. the cases of Lasswell et al. (1949), Stone et al. (1966) and Gerbner et al. (1969), could save the field from reinventing wheels. Thirdly, a comprehensive review of a variety of computer software in content analysis such as that conducted by Beattie et al, (2004) would be also of particular interest.

\section{References}

Abbott, W.F. and Monsen, R.J. (1979), "On the measurement of corporate social responsibility: self-reported disclosures as a method of measuring corporate social involvement", Academy of Management Journal, Vol. 22, No. 3, pp. 501-515.

Adams, C.A. and Harte, G. (1998), "The changing portrayal of the employment of women in British banks' and retail companies' corporate annual reports", Accounting, Organizations and Society, Vol. 23, No. 8, pp. 781-812.

Adams, C.A. and Narayanan, V. (2007), "The 'standardization' of sustainability reporting", in J. Unerman, J. Bebbington and B. O'Dwyer (Eds.), Sustainability Accounting and Accountability, Routledge, London, pp. 70-85.

Adams, C.A. and Petrella, L. (2010), "Collaboration, connections and change", Sustainability Accounting, Management and Policy Journal, Vol. 1, No. 2, pp. 292296.

Adams, C.A., Coutts, A. and Harte, G. (1995), "Corporate equal opportunities (non) disclosure”, British Accounting Review, Vol. 27, No. 2, pp. 87-108.

Adams, C.A., Wan-Ying H. and Roberts, C. (1998), "Corporate social reporting practices in Western Europe: legitimating corporate behaviour?", British Accounting Review, Vol. 30, pp. 1-21.

Ahmed, K., Chalmers, K. and Khlif, H. (2013), "A meta-analysis of IFRS adoption effects", The International Journal of Accounting, Vol. 48, pp. 173-217.

Albertini, E. (2013), "A descriptive analysis of environmental disclosure: a longitudinal study of French companies”, Journal of Business Ethics, DOI: 10.1007/s10551-0131698-y.

Barcus, F. E. (1969) "Education in content analysis: a survey", in G. Gerbner, O.R. Holsti, K. Krippendorff, W.J. Paisley and P.J. Stone (Eds.), The analysis of 
communication Content: Developments in Scientific Theories and Computer Techniques, John Wiley and Sons, New York, pp. 539-554.

Beattie, V. and Thomson, S.J. (2007), "Lifting the lid on the use of content analysis to investigate intellectual capital disclosures", Accounting Forum, Vol. 31, pp. 129-163.

Beattie, V., McInnes, B. and Feanley, S. (2004), "A methodology for analysing and evaluating narratives in annual reports: a comprehensive descriptive profile and metrics for disclosure quality attributes", Accounting Forum, Vol. 28, pp. 205-236.

Belkaoui, A. and Karpik, P. (1989), "Determinants of the corporate decision to disclose social information", Accounting, Auditing and Accountability Journal, Vol. 2, No. 1, pp. 36-51.

Bell, E. and Bryman, A. (2007), "The ethics of management research: an exploratory content analysis", British Journal of Management, Vol. 18, pp. 63-77.

Berelson, B. (1952), Content Analysis in Communication Research, Free Press, New York.

Bodolica, V. and Spraggon, M. (2013), "An examination into the disclosure, structure, and contents of ethical codes in publicly listed acquiring firms", Journal of Business Ethics, DOI: 10.1007/s10551-013-1966-x.

Borkowski, S.C. (1996), "An analysis (meta- and otherwise) of multinational transfer pricing research", The International Journal of Accounting, Vol. 31, No. 1, pp. 3953).

Boyatzis, R.E. (1998), Transforming Qualitative Information: Thematic Analysis and Code Development, Sage, Thousand Oaks, CA.

Brown, N. and Deegan, C. (1998), "The public disclosure of environmental performance information - a dual test of media agenda setting theory and legitimacy theory", Accounting and Business Research, Vol. 29, No. 1, pp. 21-41.

Bryman, A. and Bell, E. (2007), Business Research Methods, $2^{\text {nd }}$ Ed., Oxford University Press, Oxford.

Buhr, N. (1998), "Environmental performance, legislation and annual report disclosure: the case of acid rain and Falconbridge", Accounting, Auditing and Accountability Journal, Vol. 11, No. 2, pp. 163-190.

Burritt, R.L. and Welch, S. (1997), "Australian Commonwealth entities: an analysis of their environmental disclosures", Abacus, Vol. 33, No. 1, pp. 69-87.

Campbell, D. (2000), "Legitimacy theory or managerial reality construction? Corporate social disclosure in Marks and Spencer Plc corporate reports, 1969-1997", Accounting Forum, Vol. 24, No. 1, pp. 80-100.

Campbell, D., Craven, B. and Shrives, P. (2003), "Voluntary social reporting in three FTSE sectors: a comment on perception and legitimacy", Accounting, Auditing and Accountability Journal, Vol. 16, No. 4, pp. 558-581.

Cho, C.H., Roberts, R.W. and Patten, D.M. (2010), "The language of US corporate environmental disclosure", Accounting, Organizations and Society, Vol. 35, pp. 431443.

Clarkson, M., Li, Y,, Richardson, G.D. and Vasvari, F.P. (2008), "Revisiting the relation between environmental performance and environmental disclosure: an empirical analysis", Accounting, Organizations and Society, Vol. 33, pp. 303-327. 
Cowen, S.S., Ferreri, L.B. and Parker, L.D. (1987), "The impact of corporate characteristics on social responsibility disclosure: a typology and frequency-based analysis", Accounting, Organizations and Society, Vol. 12, No. 2, pp. 111-122.

Coetzee, C.M. and van Staden, C.J. (2011), "Disclosure responses to mining accidents: South African Evidence", Accounting Forum, Vol. 35, pp. 232-246.

Cormier, D and Gordon, I. (2001), "An examination of social and environmental reporting strategies", Accounting, Auditing and Accountability Journal, Vol. 14, No. 5, pp. 587-616.

Cowton, J.C. (1998), "The use of secondary data in business ethics research", Journal of Business Ethics, Vol. 17, pp. 423-434.

Deegan, C. (2007), "Social accounting research: an Australasian perspective", in R. Gray and J. Guthrie (Eds.), Social accounting, mega accounting and beyond: a festschrift in honour of M.R. Mathews, CSEAR Publishing, St. Andrews, UK, pp. 11-21.

Deegan, C. and Gordon, B. (1996), "A study of the environmental disclosure practices of Australian corporations", Accounting and Business Research, Vol. 26, No. 3, pp. 187-199.

Deegan, C. and Rankin, M. (1996), "Do Australian companies report environmental news objectively? An analysis of environmental disclosures by firms prosecuted successfully by the Environmental Protection Authority", Accounting, Auditing and Accountability Journal, Vol. 9, No. 2, pp. 50-67.

Deegan, C. and Soltys, S. (2007), "Social accounting research: an Australasian perspective", Accounting Forum, Vol. 31, pp. 73-89.

Deegan, C., Rankin, M. and Tobin, J. (2002), "An examination of the corporate social and environmental disclosures of BHP from 1983-1997", Accounting, Auditing and Accountability Journal, Vol. 15, No. 3, pp. 312-343.

Deegan, C., Rankin, M. and Voght, P. (2000), "Firms' disclosure reactions to major social incidents: Australian evidence", Accounting Forum, Vol. 24, No. 1, pp. 101130.

Deese, J. (1969), "Conceptual categories in the study of content", in G. Gerbner, O.R. Holsti, K. Krippendorff, W.J. Paisley and P.J. Stone (Eds), The Analysis of Communication Content: Developments in Scientific Theories and Computer Techniques, John Wiley and Sons, New York, pp. 39-56.

Dewey, M.E. (1983), "Coefficients of agreement”, British Journal of Psychiatry, Vol. 143, pp. 487-489.

Dierkes, M. (1979), "Corporate social reporting in Germany: conceptual developments and practical experience", Accounting, Organizations and Society, Vol. 4, No. 1/2, pp. 87-107.

Duriau, V.J., Reger, R.K. and Pfarrer, M.D. (2007), "A content analysis of the content analysis literature in Organization Studies: research themes, data sources, and methodological refinements", Organizational Research Methods, Vol. 10, No. 5, pp. 5-34.

Egger, M, Davey Smith, G and Altman, D G. (eds.) (2001), Systematic Reviews in Health Care: Meta-Analysis in Context, $2^{\text {nd }}$ Ed., BMJ Publishing House, London.

Erwin, P.M. (2011), "Corporate codes of conduct: the effects of code content and quality on ethical performance", Journal of Business Ethics, Vol. 99, pp. 535-548. 
Esrock, S.L. and Leichty, G.B. (1998), "Social responsibility and corporate web pages: self-presentation or agenda-setting?" Public Relations Review, Vol. 24, No. 3, pp. 305-319.

Freedman, M. and Jaggi, B. (2010), "Global warming and corporate disclosures: a comparative analysis of companies from the European Union, Japan and Canada", Advances in Environmental Accounting and Management, Vol. 4, pp. 129-160.

Frost, G., Jones, S. Loftus, J. and van der Laan, S. (2005), "A survey of sustainability reporting practices of Australian reporting entities", Australian Accounting Review, Vol. 15, pp. 89-95.

Gao, S.S., Heravi, S. and Xiao, J.Z. (2005), "Determinants of corporate social and environmental reporting in Hong Kong: a research note", Accounting Forum, Vol. 29 , pp. 233-242.

Gerbner, G., Holsti, O.R., Krippendorff, K., Paisley, W.J. and Stone, P.J. (Eds) (1969), The analysis of communication content: developments in scientific theories and computer techniques, John Wiley and Sons, New York.

Geyskens, I., Krishnan, R., Steenkamp, J-B.E.M. and Cunha, P.V. (2009), "A review and evaluation of meta-analysis practices in management research", Journal of Management, Vol. 35, No. 2, pp. 393-419.

Gibbins, M., Richardson, A. and Waterhouse, J. (1990), "The management of corporate financial disclosure: opportunism, ritualism, policies and processes", Journal of Accounting Research, Vol. 28, No. 1, pp. 121- 143.

Glasziou, P., Irwig, L., Bain, C. and Colditz, G. (2001), Systematic reviews in health care, Cambridge University Press, Cambridge.

Gray, R. and Hoepner, A.G.F. (2011), "PLEASE CITE THIS: an exploratory paper on citations, impacts and the social accounting literature", Social and Environmental Accounting Journal, Vol. 31, No. 1, pp. 25-47.

Gray, R., Javad, M. Power, D.M. and Sinclair, C.D. (2001), "Social and environmental disclosure and corporate characteristics: a research note and extension", Journal of Business Finance and Accounting, Vol. 28, No. 3-4, pp. 327-356.

Gray, R., Kouhy, R. and Lavers, S. (1995a), "Corporate social and environmental reporting: a review of the literature and a longitudinal study of UK disclosure", Accounting, Auditing and Accountability Journal, Vol. 8, No. 2, pp. 47-77.

Gray, R., Kouhy, R. and Lavers, S. (1995b), "Methodological themes: constructing a research database of social and environmental reporting by UK companies", Accounting, Auditing and Accountability Journal, Vol. 8, No. 2, pp. 78-101.

Gray, R., Owen, D. and Maunders, K. (1987), Corporate Social Reporting: Accounting and Accountability, Hemel Hempstead, Prentice Hall.

Grey, A., Kaplan, D. and Lasswell, H.D. (1949), "Recording and context units - four ways of coding editorial content", in H.D. Lasswell, N. Leites and Associates (Eds.), Language of Politics: Studies in Quantitative Semantics, The MIT Press, Cambridge, MA, pp. 113-126.

GRI (Global Reporting Initiative) (2013), G4 Sustainability Reporting Guidelines, GRI, Boston.

Gunawan, J. (2007), "Corporate social disclosures by Indonesian listed companies: a pilot study”, Social Responsibility Journal, Vol. 3, No. 3, pp. 26-34. 
Guthrie, J.E. and Mathews, M.R. (1985), "Corporate social accounting in Australasia", Research in Corporate Social Performance and Policy, Vol. 7, pp. 251-277.

Guthrie, J.E., Cuganesan, S. and Ward, L. (2008), "Disclosure media for social and environmental matters within the Australian food and beverage industry", Social and Environmental Accounting Journal, Vol. 28, No. 1, pp. 33-44.

Guthrie, J.E., Petty, R. and Yongvanich, K. (2004), "Using content analysis as a research method to inquire into intellectual capital reporting", Journal of Intellectual Capital, Vol. 5, No. 2, pp. 282-293.

Hackston, D. and Milne, M.J. (1996), "Some determinants of social and environmental disclosures in New Zealand companies", Accounting, Auditing and Accountability Journal, Vol. 9, No. 1, pp. 77-108.

Haddock-Fraser, J. (2012), "The role of the news media in influencing corporate environmental sustainable development: an alternative methodology to assess stakeholder engagement", Corporate Social Responsibility and Environmental Management, Vol. 19, pp. 327-242.

Hasseldine, J., Salama, A.I. and Toms, J.S. (2005), "Quantity versus quality: the impact of environmental disclosures on the reputations of UK Plcs", The British Accounting Review, Vol. 37, pp. 231-248.

Hoepner, A.G.F. and Unerman, J. (2012), "Explicit and implicit subject bias in the $A B S$ Journal Guide", Accounting Education: an international journal, Vol. 21, No. 1, pp. $3-15$.

Holsti, O.R. (1969), Content Analysis for the Social Sciences and Humanities, AddisonWesley Publishing Company, Reading, MA.

Howell Major, C. and Savin-Baden, M. (2010), "Qualitative research synthesis: the scholarship of integration in practice", in M. Savin-Baden and C. Howell Major (Eds.), New approaches to qualitative research: wisdom and uncertainty, Routledge, London, pp. 108-118).

Ingram, R.W. and Frazier, K.B. (1980), "Environmental performance and corporate disclosure", Journal of Accounting Research, Vol. 18, No. 2, pp. 614-622.

Islam, M.A. and Deegan, C. (2010), "Media pressures and corporate disclosure of social responsibility performance information: a study of two global clothing and sports retail companies", Accounting and Business Research, Vol. 40, No. 2, pp. 131-148.

Jefferson, T., Price, D., Demicheli, V. and Bianco, E. (2003), "Unintended events following immunization with MMR: a systematic review", Vaccine, Vol. 21, pp. 3954-3960.

Kelly, G.J. (1981), “Australian social responsibility disclosure: some insights into contemporary measurement", Accounting and Finance, Vol. 20, No. 3, pp. 97-107.

Krippendorff, K. (1969), 'Theories and analytical constructs: introduction', in G. Gerbner, O.R. Holsti, K. Krippendorff, W.J. Paisley and P.J. Stone (Eds), The Analysis of Communication Content: Developments in Scientific Theories and Computer Techniques, John Wiley and Sons, New York, pp. 3-16.

Krippendorff, K. (2004), Content Analysis: An Introduction to its Methodology, 2nd Ed., Sage, Thousand Oaks, CA.

Krippendorff, K. (2013), Content Analysis: An Introduction to its Methodology, 3rd Ed., Sage, Thousand Oaks, CA. 
Lasswell, H.D. (1949), "Why be Quantitative?" in H.D. Lasswell, N. Leites and Associates (Eds.), Language of Politics: Studies in Quantitative Semantics, The MIT Press, Cambridge, MA, pp. 40-52

LeCompte, M.D. and Goetz, J.P. (1982), "Problems of reliability and validity in ethnographic research", Review of Educational Research, Vol. 52, No. 1, pp. 31-60.

Lewis-Beck, M.S., Bryman, A. and Futing Liao, T. (2004), The SAGE Encyclopedia of Social Science Research Methods, Sage, Thousand Oaks, CA.

Lombard, M., Snyder-Duch, J. and Bracken, C.C. (2002), "Content analysis in mass communication: assessment and reporting of intercoder reliability", Human Communication Research, Vol. 28, pp. 587-604.

Magness, V. (2010), "Environmental disclosure in the mining industry: a signalling paradox?" Advances in Environmental Accounting and Management, Vol. 4, pp. 5581.

Mahadeo, J.D., Oogarah-Hanuman, V. and Soobaroyen, T. (2011), "Changes in social and environmental reporting practices in an emerging economy (2004-2007): exploring the relevance of stakeholder and legitimacy theories", Accounting Forum, Vol. 35, pp. 158-175.

Marr, B., Gray, D. and Neely, A. (2003), "Why do firms measure their intellectual capital?" Journal of Intellectual Capital, Vol. 4, No. 4, pp. 441-464.

Merkl-Davies, D., Brennan, N. and Vourvachis, P. (2011). Text analysis methodologies in corporate narrative reporting research, paper presented in the 23rd CSEAR International Congress on Social and Environmental Accounting Research, St. Andrews, UK, 7-9 September.

Milne, M.J. and Adler, R.W. (1999), "Exploring the Reliability of Social and Environmental Disclosures Content Analysis", Accounting, Auditing and Accountability Journal, Vol. 12, No. 2, pp. 237-256.

Milne, M.J. and Gray, R. (2007). "Future prospects for corporate sustainability reporting", in Unerman, J., Bebbington, J. and O'Dwyer, B. (Eds.), Sustainability Accounting and Accountability, Routledge, London, pp. 184-207.

Oats, L. (2012), "On methods and methodology", in L. Oats (Ed), Taxation: A Fieldwork Handbook, Routledge, Oxon, pp. 9-18.

Ortiz-Martinez, E. and Crowther, D. (2008), "Is disclosure the right way to comply with stakeholders? The Shell case", Business Ethics: A European Review, Vol. 17, No. 1, pp. 13-22.

Osgood, C.E. (1959). "The representational model and relevant research methods", in I de S. Pool (Ed.), Trends in Content Analysis, University of Illinois Press, Urbana, pp. 33-88.

Patten, D.M. (2002a), "Media exposure, public policy pressure, and environmental disclosure: an examination of the impact of tri data availability", Accounting Forum, Vol. 26, No. 2, pp. 152-171.

Patten, D.M. (2002b), "The relation between environmental performance and environmental disclosure: a research note", Accounting, Organizations and Society, Vol. 27, No. 8, pp. 763-773.

Patten, D.M. and Crampton, W. (2004), "Legitimacy and the internet: an examination of corporate web page environmental disclosures", Advances in Environmental Accounting and Management, Vol. 2, pp. 31-57. 
Payne, G.T., Brigham, K.H., Broberg, J.C., Moss, T.W. and Short, J.C. (2011), "Organizational virtue orientation and family firms", Business Ethics Quarterly, Vol. 21, No. 2, pp. 257-285.

Pool, I.S. (Ed.) (1959), Trends in Content Analysis, University of Illinois Press, Urbana, IL.

Potter, W.J. and Levine-Donnerstein, D. (1999), "Rethinking validity and reliability in content analysis", Journal of Applied Communication Research, Vol. 27, pp. 258284.

Price, D., Jefferson, T. and Demicheli, V. (2004), "Methodological issues arising from systematic reviews of the evidence of safety of vaccines", Vaccine, Vol. 22, pp. 2080 $-2084$.

Riffe, D. and Freitag, A. (1997), "A content analysis of content analyses: twenty-five years of Journalism Quarterly", Journalism and Mass Communication Quarterly, Vol. 74, No. 4, pp. 873-882.

Ritchie, J. and Lewis, J. (2003), Qualitative Research Practice: A Guide for Social Science Students and Researchers, London, Sage.

Rosengren, K.E. (Ed.) (1981), Advances in Content Analysis, Sage, Beverly Hills, CA.

Rowbottom, N. and Lymer, A. (2009), "Exploring the use of online corporate sustainability information", Accounting Forum, Vol. 33, 176-186.

Rutherford, B.A. (2005), "Genre analysis of corporate annual report narratives", Journal of Business Communication, Vol. 42, No. 4, pp. 349-378.

Savage, A., Cataldo, A.J. and Rowlands, J. (2000), "A multi-case investigation of environmental legitimation in annual reports", Advances in Environmental Accounting and Management, Vol. 1, pp. 45-81.

Sawani, Y., Zain, M.M. and Darus, F. (2010), "Preliminary insights on sustainability reporting and assurance practices in Malaysia", Social Responsibility Journal, Vol. 6, No. 4, pp. 627-645.

Schwandt, T.A. (2007), The SAGE dictionary of qualitative inquiry, $3^{\text {rd }}$ Ed., Sage, Thousand Oaks, CA.

Sepstrup, P. (1981), "Methodological Developments in Content Analysis?", in K.E. Rosengren (Ed.), Advances in Content Analysis, Sage, Beverley Hills, CA, pp. 133158.

Smith, M. and Taffler, R.J. (2000), “The chairman's statement: a content analysis of discretionary narrative disclosures", Accounting, Auditing and Accountability Journal, Vol. 13, No. 5, pp. 624-646.

Steenkamp, N. and Northcott, D. (2007), "Content analysis in accounting research: the practical challenges", Australian Accounting Review, Vol. 17, No. 3, pp. 12-25.

Stone, P.J, Dunphy, D.C., Smith, M.S. and Ogilvie, D.M. (1966), The General Inquirer: A Computer Approach to Content Analysis, MIT Press, Cambridge.

Strauss, A. and Corbin, J. (1998), Basics of Qualitative Research, $2^{\text {nd }}$ Ed., Sage, London.

Tashakkori, A. and Teddlie, C. (1998), Mixed Methodology: Combining Qualitative and Quantitative Approaches, Sage, London.

Tennyson, B.M., Ingram, R.W. and Dugan, M.T. (1990), "Assessing the information content of narrative disclosures in explaining bankruptcy", Journal of Business Finance and Accounting, Vol. 17, No. 3, pp. 391-410. 
Thomson, I. (2007), "Mapping the terrain of sustainability accounting", in J. Unerman, J. Bebbington and B. O'Dwyer (Eds.), Sustainability accounting and accountability, Routledge, Oxon, pp. 19-36.

Tilling, M. and Tilt, C.A. (2010), "The edge of legitimacy: voluntary social and environmental reporting in Rothmans' 1956-1999 annual reports", Accounting, Auditing and Accountability Journal, Vol. 23, No. 1, pp. 55-81.

Turner, G., Vourvachis, P. and Woodward, T. (2006), "Heading towards sustainability reporting: a pilot study into the progress of embracing the Global Reporting Initiative in the United Kingdom”, Journal of Applied Accounting Research, Vol. 8, No. 2, pp. 41-70.

Unerman, J. (2000), "Methodological issues: reflections on quantification in corporate social reporting content analysis", Accounting, Auditing and Accountability Journal, Vol. 13, No. 5, pp. 667-680.

Volkens, A. (2007), "Strengths and weaknesses of approaches to measuring policy positions of parties", Electoral Studies, Vol. 26, 108-120.

Walden, W.D. and Stagliano, A.J. (2003), "An assessment of the quality of environmental disclosure themes", Advances in Environmental Accounting and Management, Vol. 2, pp. 137-165.

Walker, K. (2010), "A systematic review of the corporate reputation literature: definition, measurement, and theory", Corporate Reputation Review, Vol. 12, No. 4, pp. 357 387.

Weber, R. (1990), Basic Content Analysis, $2^{\text {nd }}$ Ed., Sage, Newbury Park, CA.

Weber, R. (2004), "Editor's comments: the rhetoric of positivism versus interpretivism: a personal view", Management Information Systems Quarterly, Vol. 28, No. 1, pp. iiixii.

Wilmshurst, T.D. and Frost, G.R. (2000), "Corporate environmental reporting: a test of legitimacy theory", Accounting, Auditing and Accountability Journal, Vol. 13, No. 1, pp. 10-26.

Wiseman, J. (1982), “An evaluation of environmental disclosures made in corporate annual reports", Accounting, Organizations and Society, Vol. 7, No. 1, pp. 53-63.

Yamagami, T. and Kokubu, K. (1991), “A note on corporate social disclosure in Japan”, Accounting, Auditing and Accountability Journal, Vol. 4, No. 4, pp. 32-39.

Zéghal, D. and Ahmed, S.A. (1990), "Comparison of social responsibility information disclosure media used by Canadian firms", Accounting, Auditing and Accountability Journal, Vol. 3, No. 1, pp. 38-53. 
Figures and tables

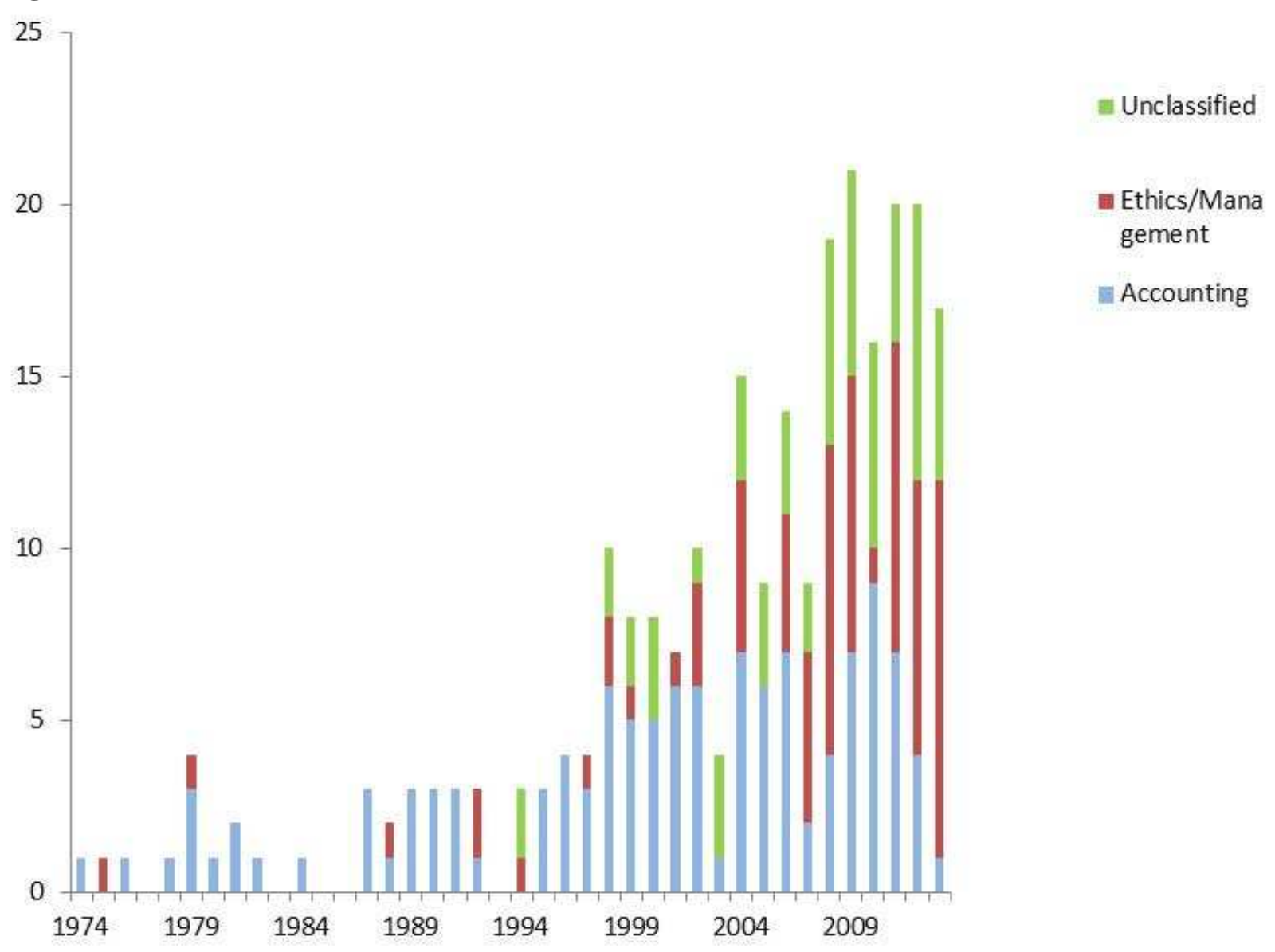

Figure 1 Articles using content analysis 

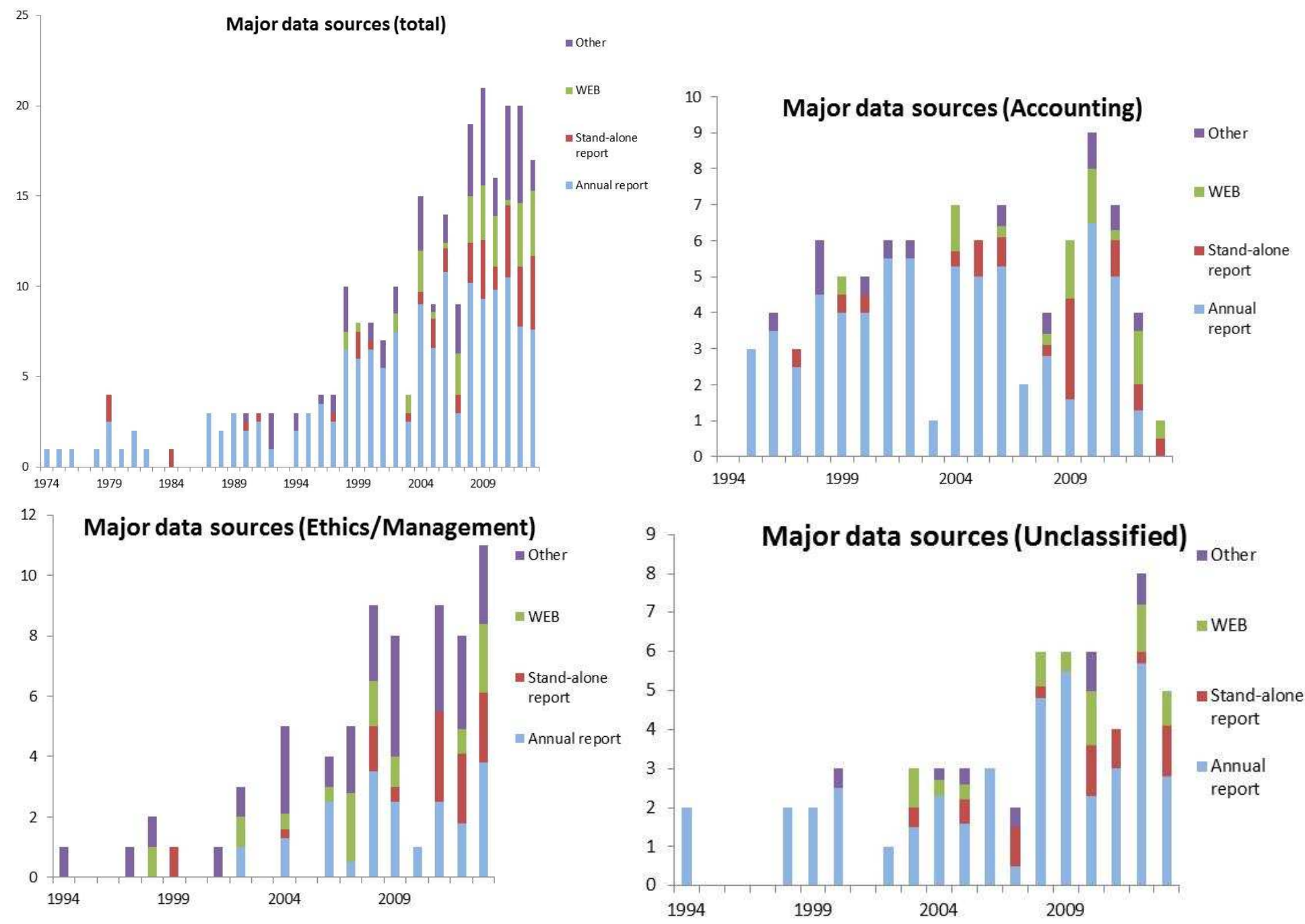

Figure 2 Major data sources 

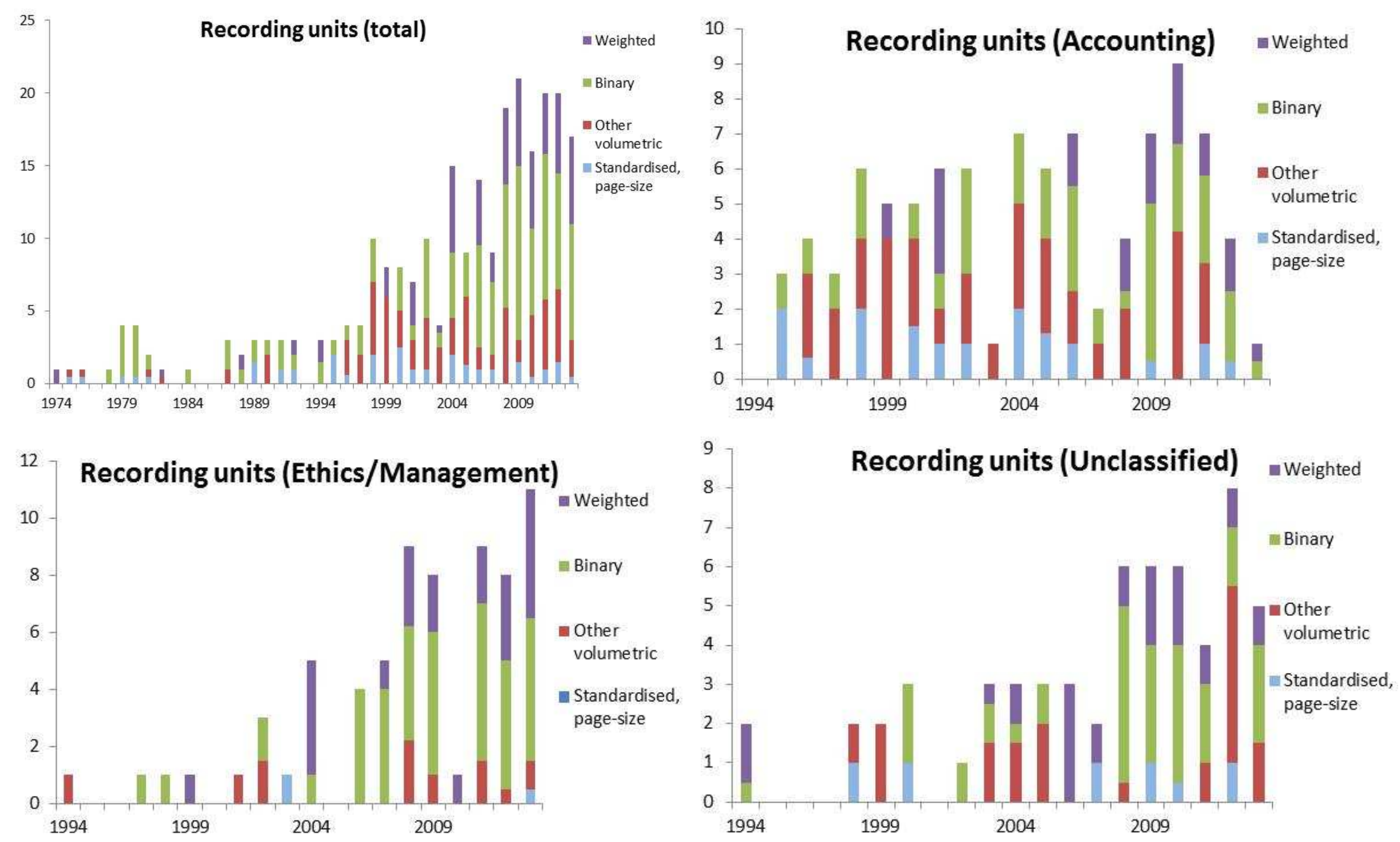

Figure 3 Recording units 

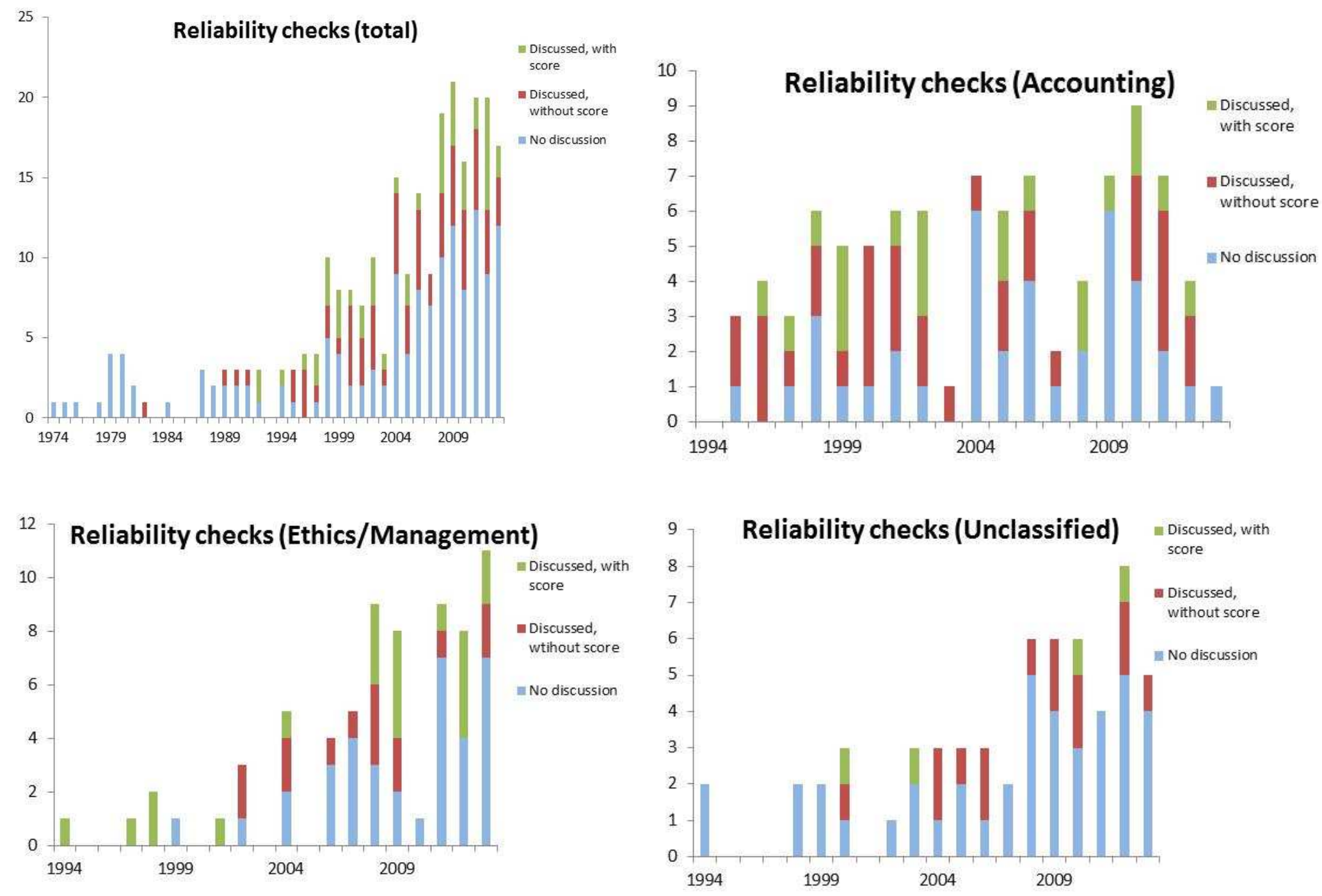

Figure 4 Reliability checks 

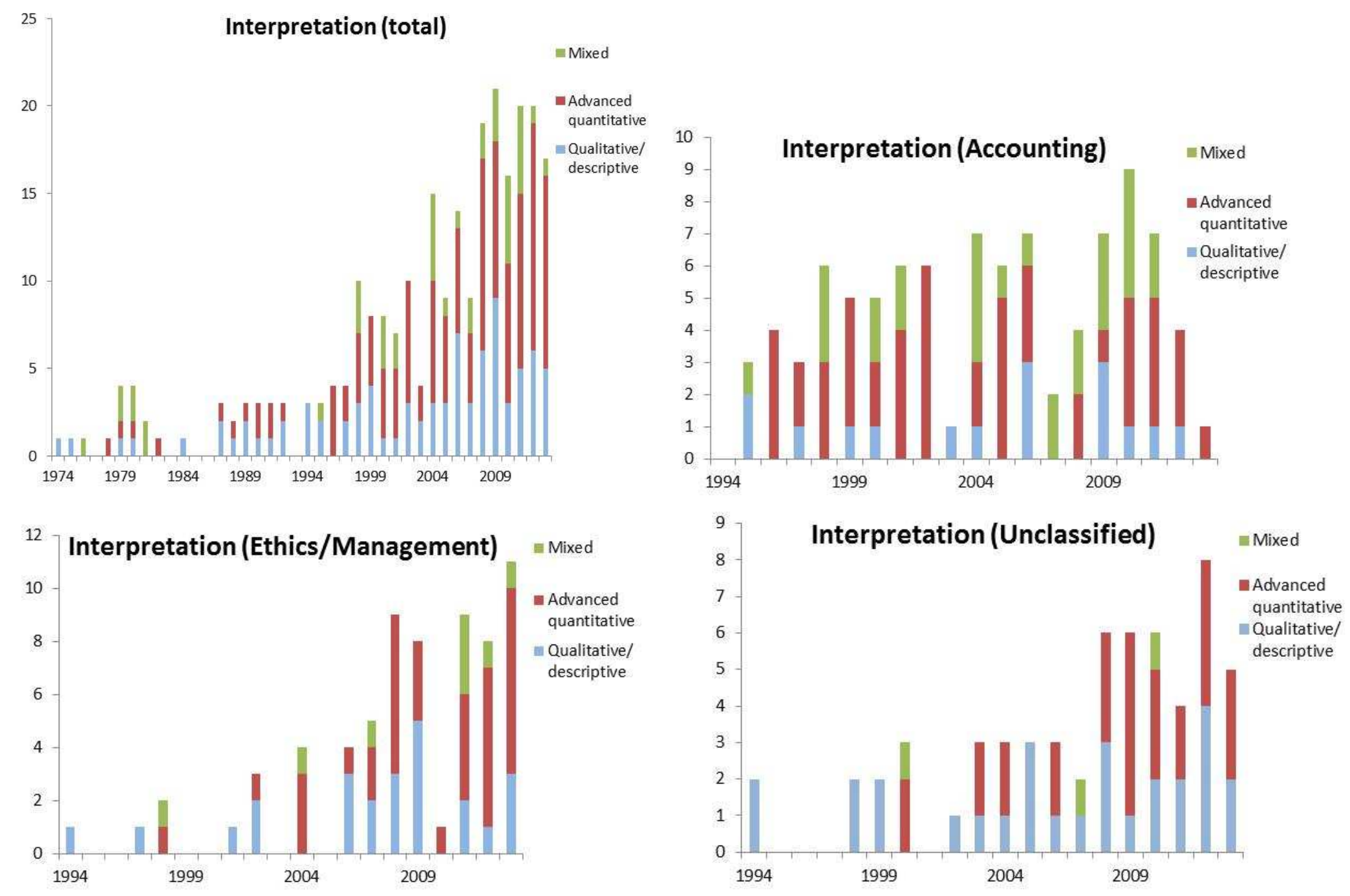

Figure 5 Interpretation 
Table 1 A suggested content analysis typology

\begin{tabular}{|l|c|c|c|}
\hline & Form oriented & \multicolumn{2}{|c|}{ Meaning oriented } \\
\hline Content & Manifest & \multicolumn{2}{|c|}{ Latent } \\
\hline $\begin{array}{l}\text { Communication } \\
\text { aspect }\end{array}$ & Syntactic & Semantic & Pragmatic \\
\hline Categories & $\begin{array}{c}\text { Standard or } \\
\text { custom }\end{array}$ & $\begin{array}{c}\text { Deductive or } \\
\text { abductive }\end{array}$ & $\begin{array}{c}\text { Inductive or } \\
\text { abductive }\end{array}$ \\
\hline Theory & Not relevant & $\begin{array}{c}\text { Basis for coding } \\
\text { scheme }\end{array}$ & Theory building \\
\hline Orientation & \multicolumn{2}{|c|}{ Quantitative } & Qualitative \\
\hline
\end{tabular}

Table 3 Recording units' consideration of an array of issues of concern

\begin{tabular}{|c|c|c|c|c|c|}
\hline & Words & Sentences & $\begin{array}{c}\text { Standardis } \\
\text { ed }\end{array}$ & $\begin{array}{c}\text { Page size } \\
\text { data }\end{array}$ \\
\hline \multirow{7}{*}{ 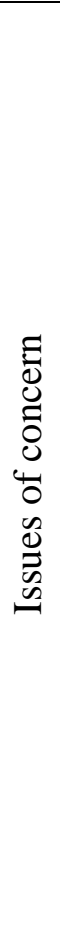 } & $\begin{array}{l}\text { Inclusion of } \\
\text { images/graphs, } \\
\text { Large typeface } \\
\text { within report }\end{array}$ & & & & \\
\hline & $\begin{array}{l}\text { Subjective } \\
\text { measurements and } \\
\text { internet }\end{array}$ & & & & \\
\hline & $\begin{array}{l}\text { Report physical } \\
\text { size and font size; } \\
\text { margins and blank } \\
\text { pages; pdf and } \\
\text { microfiche forms }\end{array}$ & & & & \\
\hline & $\begin{array}{l}\text { Detail in } \\
\text { measurements }\end{array}$ & & & & \\
\hline & $\begin{array}{l}\text { Ease, errors in } \\
\text { measurements }\end{array}$ & & & & \\
\hline & Inclusion of tables & & & & \\
\hline & $\begin{array}{l}\text { Grammar and } \\
\text { repetition }\end{array}$ & & & & \\
\hline
\end{tabular}


Table 2 Summary of index analysis findings

\begin{tabular}{|c|c|c|c|}
\hline & Form-oriented & Meaning-oriented & Total sample \\
\hline & $160(64 \%)$ & $91(36 \%)$ & 251 \\
\hline $\begin{array}{l}\text { Research questions } \\
\text { - What is being disclosed } \\
\text { - } \quad \text { Why is being disclosed } \\
\text { - } \quad \text { What are the determinants/ } \\
\text { relations of disclosure } \\
\text { - Other }\end{array}$ & $\begin{array}{l}85(53 \%) \\
15(9 \%) \\
22(14 \%) \\
38(24 \%)\end{array}$ & $\begin{array}{l}37(41 \%) \\
21(23 \%) \\
7(8 \%) \\
26(29 \%)\end{array}$ & $\begin{array}{l}122(49 \%) \\
36(14 \%) \\
29(12 \%) \\
64(25 \%)\end{array}$ \\
\hline \begin{tabular}{ll}
\multicolumn{2}{l}{ Theory } \\
- & Legitimacy theory \\
- & Stakeholder theory \\
- & Institutional theory \\
- & Other \\
- & No explicit framework
\end{tabular} & $\begin{array}{l}34(21 \%) \\
14(9 \%) \\
8(5 \%) \\
26(40 \%) \\
78(49 \%) \\
\end{array}$ & $\begin{array}{l}36(40 \%) \\
13(14 \%) \\
3(3 \%) \\
12(13 \%) \\
27(30 \%) \\
\end{array}$ & $\begin{array}{l}70(29 \%) \\
27(11 \%) \\
11(4 \%) \\
38(15 \%) \\
105(42 \%) \\
\end{array}$ \\
\hline 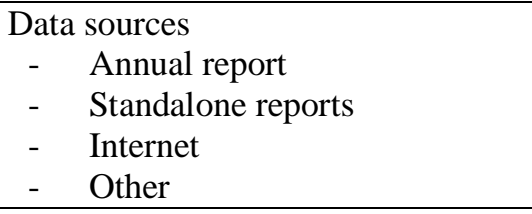 & $\begin{array}{l}118(74 \%) \\
27(17 \%) \\
24(15 \%) \\
31(19 \%) \\
\end{array}$ & $\begin{array}{l}74(81 \%) \\
39(43 \%) \\
12(13 \%) \\
24(27 \%) \\
\end{array}$ & $\begin{array}{l}192(76 \%) \\
66(26 \%) \\
36(14 \%) \\
55(22 \%)\end{array}$ \\
\hline $\begin{array}{ll}\text { Categories } \\
\text { - } & \text { Disclosure theme } \\
- & \text { Positive vs. negative } \\
- & \text { Monetary vs. non-monetary } \\
- & \text { Other }\end{array}$ & $\begin{array}{l}160(100 \%) \\
27(17 \%)\end{array}$ & $\begin{array}{l}90(99 \%) \\
23(25 \%) \\
35(38 \%) \\
42(46 \%)\end{array}$ & $\begin{array}{l}250(100 \%) \\
23(9 \%) \\
62(25 \%) \\
42(17 \%)\end{array}$ \\
\hline $\begin{array}{l}\text { Measurement } \\
\text { Index } \\
-\quad \text { Binary } \\
-\quad \text { Weighted } \\
\text { Volumetric } \\
-\quad \text { Words } \\
-\quad \text { Sentences } \\
-\quad \text { Pages (ST, PS) } \\
-\quad \text { Other }\end{array}$ & $\begin{array}{l}119(74 \%) \\
85(53 \%) \\
36(23 \%) \\
56(35 \%) \\
9(6 \%) \\
20(13 \%) \\
22(14 \%) \\
6(4 \%) \\
\end{array}$ & $\begin{array}{l}58(64 \%) \\
34(37 \%) \\
29(32 \%) \\
45(49 \%) \\
15(16 \%) \\
19(21 \%) \\
10(11 \%) \\
4(4 \%) \\
\end{array}$ & $\begin{array}{l}177(71 \%) \\
119(47 \%) \\
65(26 \%) \\
101(40 \%) \\
24(10 \%) \\
39(15 \%) \\
32(13 \%) \\
10(4 \%) \\
\end{array}$ \\
\hline \begin{tabular}{ll}
\multicolumn{2}{l}{ Design } \\
- & Inductive \\
- & Deductive \\
- & Abductive
\end{tabular} & $160(100 \%)$ & $\begin{array}{l}10(11 \%) \\
63(69 \%) \\
19(21 \%)\end{array}$ & $\begin{array}{l}10(4 \%) \\
223(89 \%) \\
19(7 \%)\end{array}$ \\
\hline $\begin{array}{l}\text { Longitudinal } \\
-\quad \text { Cross-sectional }\end{array}$ & $\begin{array}{l}61(38 \%) \\
99(62 \%)\end{array}$ & $\begin{array}{l}56(62 \%) \\
35(38 \%)\end{array}$ & $\begin{array}{l}117(47 \%) \\
134(53 \%)\end{array}$ \\
\hline \begin{tabular}{ll}
\multicolumn{2}{l}{ Interpretation } \\
- & Qualitative \\
- & Descriptive quantitative \\
- & Advanced quantitative \\
- & Mixed
\end{tabular} & $\begin{array}{l}5(3 \%) \\
55(34 \%) \\
80(50 \%) \\
20(13 \%)\end{array}$ & $\begin{array}{l}3(3 \%) \\
19(21 \%) \\
51(56 \%) \\
18(20 \%)\end{array}$ & $\begin{array}{l}8(3 \%) \\
74(30 \%) \\
131(52 \%) \\
38(15 \%)\end{array}$ \\
\hline $\begin{array}{ll}\text { Reliability checks } \\
\text { - } & \text { No explicit discussion } \\
\text { - } & \text { Yes, without providing scores } \\
\text { - } & \text { Yes, by providing scores }\end{array}$ & $\begin{array}{l}97(61 \%) \\
34(21 \%) \\
29(18 \%)\end{array}$ & $\begin{array}{l}40(44 \%) \\
33(36 \%) \\
18(20 \%)\end{array}$ & $\begin{array}{l}137(55 \%) \\
67(27 \%) \\
47(18 \%)\end{array}$ \\
\hline $\begin{array}{l}\text { Computer assisted analysis } \\
\text { - } \quad \text { Manual coding }\end{array}$ & $\begin{array}{l}2(1 \%) \\
158(99 \%)\end{array}$ & $\begin{array}{l}6(7 \%) \\
85(93 \%)\end{array}$ & $\begin{array}{l}8(3 \%) \\
243(97 \%)\end{array}$ \\
\hline
\end{tabular}

